\title{
A new case of trombiculiasis caused by Eutrombicula daemoni Bassini- Silva \& Jacinavicius, 2018 (Trombidiformes: Trombiculidae) in a dog from Brazil
}

\author{
Rodrigo Santos-Rodrigues ${ }^{1(\mathbb{1})}$, Ricardo Bassini-Silva ${ }^{1,2}$, Matheus Huang-Bastos ${ }^{1,3}$ (D),

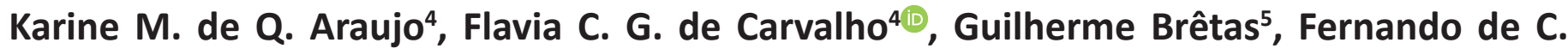 \\ Jacinavicius $\mathbf{s}^{1 \pm=(\mathbb{E})}$
}

${ }^{1}$ Laboratório de Coleções Zoológicas, Instituto Butantan, São Paulo, SP, Brazil. ${ }^{2}$ Departamento de Patologia, Reprodução e Saúde Única, Faculdade de Ciências Agrárias e Veterinárias-UNESP, Jaboticabal, SP, Brazil. ${ }^{3}$ Departamento de Medicina Veterinária Preventiva e Saúde Animal, FMVZ-USP, São Paulo, SP, Brazil. ${ }^{4}$ Equalis Instituto de Pós Graduação em Dermatologia Veterinária, São Paulo, São Paulo, Brazil. ${ }^{5}$ Clínica Veterinária Dr. Guilherme Brêtas, Vila Velha, ES, Brazil.

拝=-Corresponding author: fcjacinavicius@gmail.com

Edited by: Peterson R. Demite

Received: August 25, 2021. Accepted: October 04, 2021. Published: December 06, 2021.

\begin{abstract}
Chiggers are ectoparasites and can cause severe dermatitis in their hosts, known as trombiculiasis. Besides that, these mites can be vectors of bacteria of the genus Orientia, in various regions of the world. The genera Eutrombicula Ewing, 1938 is currently represented by more than 80 species worldwide. Species of this genus are recorded parasitizing reptiles, birds, and mammals. One of this species, Eutrombicula daemoni Bassini-Silva \& Jacinavicius, 2018 was recently described causing trombiculiasis in a dog. Our goal is to report a new case of a dog's trombiculiasis, including a new locality record for E. daemoni in Brazil. In May 2021, a female Shih-Tzu dog with three years old and with access to the forest of the Santa Tereza municipality, southeastern Brazil, sought veterinary medical attention for intense itching and erythema in the facial region. Mites were collected directly from the face of the dog. These materials were slide-mounted and deposited in the Acarological Collection of the Butantan Institute (IBSP). The material extracted from the dog was examined and identified as E. daemoni. Part of the fixation site tissue of the dog was collected, showing the feeding tube produced by the enzymatic reaction of saliva by the mite, known as a stylostome. In this report, we emphasize the occurrence of trombiculiasis in domestic animals that have access to forest regions, places that unfed chigger larvae live. Additionally, this record represents a new locality record for E. daemoni to the Espírito Santo State, Brazil.
\end{abstract}

Keywords: Chiggers, ectoparasites, Espírito Santo State, Carnivora, Canis lupus familiaris.

Chigger's larvae (Trombidiformes: Trombiculidae s. I.) are ectoparasites of wild terrestrial vertebrates, and on rare occasions, the unfed larvae can parasitize domestic animals (Takahashi et al. 2004). The genus Eutrombicula Ewing, 1938 can cause severe skin reactions in the host, known as trombiculiasis. It is characterized as circular lesions of sizes ranging from 2 to $4 \mathrm{~cm}$ in diameter. Scratching the papules cause intense pruritus resulted in large inflamed areas of the skin (Faccini et al. 2017; Bassini-Silva et al. 2019). This genus is currently represented by more than 80 species worldwide and they are recorded parasitizing reptiles, birds, and mammals (Bassini-Silva et al. 2018; 2019). Nine species were recorded in Brazil, Eutrombicula alfreddugesi (Oudemans, 1910), E. batatas (Linnaeus, 1758), E. daemoni BassiniSilva \& Jacinavicius, 2018, E. bruyanti (Oudemans, 1910), E. goeldii (Oudemans, 1910), E. ophidica (Fonseca, 1932), E. spipi Brennan \& Reed, 1974, E. tinami (Oudemans, 1910), and E. tropica (Ewing, 1925) (Bassini-Silva 2018; Jacinavicius et al. 2018).

One of these species, E. daemoni was originally described in the Minas Gerais State (Santa Bárbara do Monte Verde and Juiz de Fora municipalities, Fig. 1), parasitizing the social flycatcher, Myiozetetes similis (Spix, 1825) (Passeriformes: Tyrannidae). Later this same species was collected in a dog (Carnivora: Canidae) (Bassini-Silva et al. 2018; Sampaio et al. 2020). Considering that few cases report trombiculiasis caused by species of the genus Eutrombicula in South America, this kind of report is necessary, given the lack of information, especially in places where the fauna is practically unknown. Therefore, the present study describes a case report of a dog with trombiculiasis and a new locality (Santa Tereza municipality, Espírito Santo State, Fig. 1) for the species E. daemoni, in Brazil.

The fauna of chiggers was poorly represented in the Espírito Santo State, there are only two records. One of these records is the rare association with a chigger, Odontacarus sp., parasitizing an adult male of a whip spider, Charinus brasilianus Weygoldt, 1972 (Charinidae: Amblypygi) in Santa Teresa municipality (Gonçalves-Souza et al. 2014); the other record is the occurrence of Eutrombicula alfreddugesi s. I. on Tropidurus torquatus (Wied, 1820) (Squamata: Tropiduridae) in the São Mateus, Guarapari and Presidente Kennedy municipalities (Rocha et al. 2020).

The Butantan Institute has a representative collection of mites and ticks (IBSP) characterized mainly by parasite species associated with humans and wild/domestic animals from the Neotropical Region. Recently, we received six larvae of chiggers, fixed in ethyl alcohol P.A $100 \%$, collected on the face of a dog. On May, $31^{\text {th }} 2021$, the owner of a female Shih-Tzu dog with three years old and with access to the forest of the Santa Tereza municipality, mountainous region of the Espírito Santo State, southeastern Brazil ( $\left.19^{\circ} 56^{\prime} 07^{\prime \prime} \mathrm{S}, 40^{\circ} 33^{\prime} 50^{\prime \prime} \mathrm{W}\right)$, sought veterinary medical attention for intense itching and erythema, both in the facial region of the animal (Fig. 2A). This material was slide-mounted with Hoyer's medium according to Barros-Battesti et al. (2021), deposited in the IBSP collection under the access number IBSP 16663. The specimens were imaged using a Leica DFC 500 digital camera coupled to an optical microscope Leica DM4000B, in the Zoological Collection Laboratory, Butantan Institute, São Paulo. All the images were prepared with Adobe Photoshop v. 13.0. The chiggers were identified as Eutrombicula daemoni via comparison with the 
holotype and paratypes of this species (access number IBSP 12374B). In agreement with Bassini-Silva et al. (2019) and Sampaio et al. (2020) we confirm the set of morphological characters that separate E. daemoni from others Eutrombicula: Palptibia with dorsal and lateral setae nude, and ventral seta branched; nude adoral setae; bifurcate odontus (Odo); the first dorsal opisthosomal row (C) with ten setae; the second row (D) with eight setae; tarsus of the legs I with a famulus $(\varepsilon)$ positioned distal to solenidion $(\omega)$; tibia of the legs III with two mastisetae and tarsus of the leg III with four mastisetae.

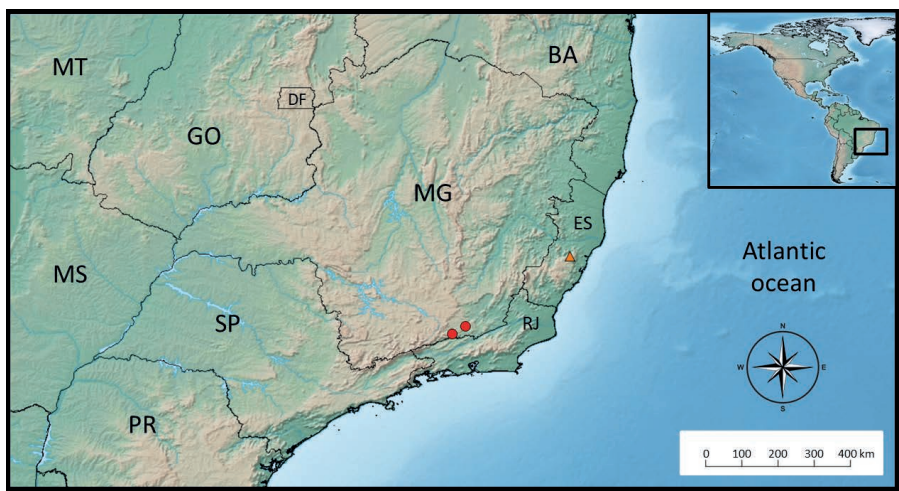

Figure 1. Distribution of Eutrombicula daemoni Bassini-Silva \& Jacinavicius, 2018. The red circles are literature records, while the orange triangle is the new record.
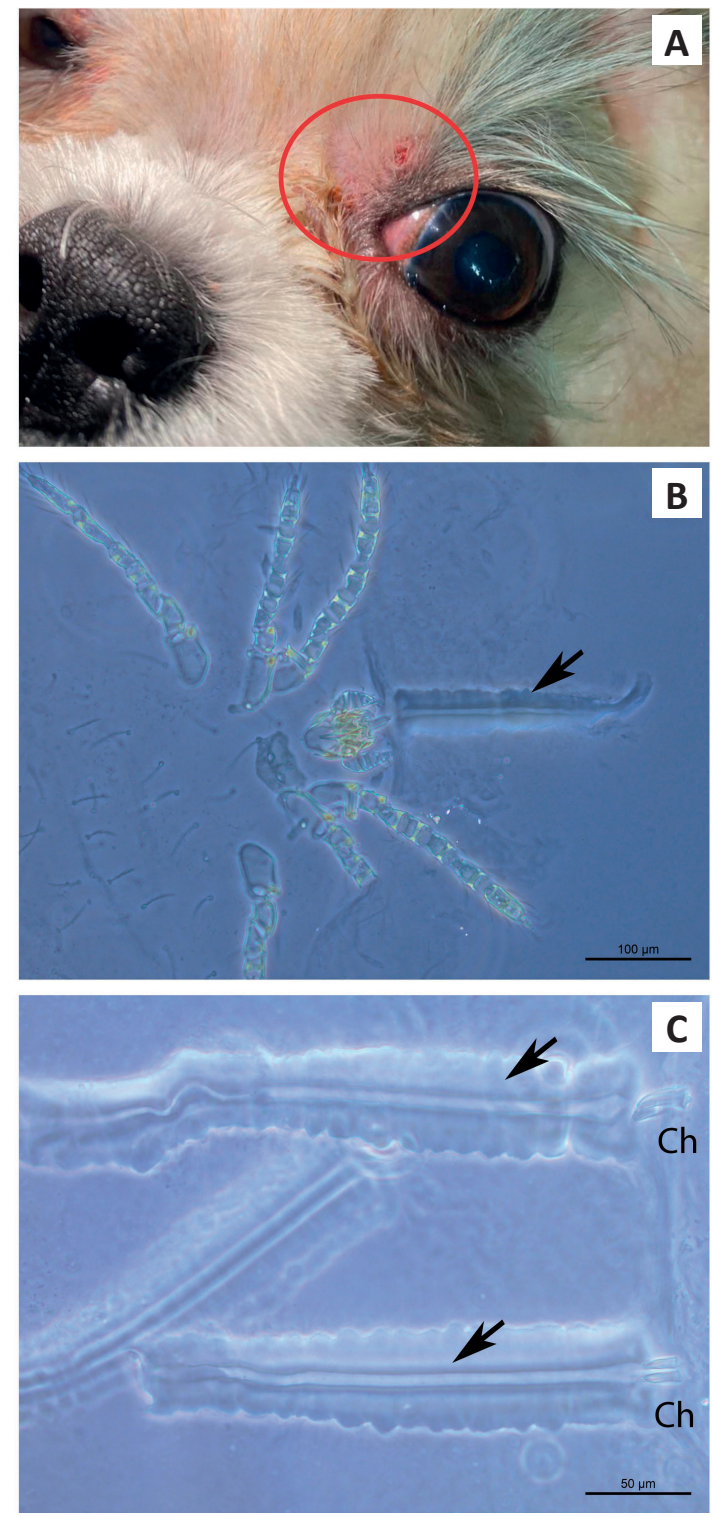

Figure 2. Eutrombicula daemoni Bassini-Silva \& Jacinavicius, 2018 larvae. (A) Host parasitism site. (B) Mite overview and stylostome formation in the host skin. (C) Detail of the stylostome. Symbols: Arrows indicate de stylostome; Ch $=$ Cheliceral blade.
During clinical examination of the host, rostral pruritus was observed due to a single papular erythematous lesion with mild dekeratinization in the right periocular and labial commissure region. In the center of the lesion, orange mites were collected by skin scraping. During parasitism, it fixes on the host's skin, and the enzymatic reaction of saliva produces a feeding tube known as a stylostome (Figs. 2B and $2 \mathrm{C}$ ). According to Shatrov \& Antonovskaia (2021), pathogens can be transmitted to their host, depending on the inflammation degree resulting from the parasitism. Treatment was carried out with Sarolaner (Simparic-zoetis) at a single dose of $2 \mathrm{mg} / \mathrm{kg}$, and after seven days, treatment efficiency was observed. A few mites had remained in the animal, but they were already dead.

Despite the number of chiggers in the world, Zhang et al. (2011) estimated the existence of approximately 3,700 chiggers species. However, trombiculiasis in dogs have been reported in several places, as in Europe (Fain \& Net 2000; Giannoulopoulos 2012; Stekolnikov et al. 2016; Lecru 2019; Apesteguía et al. 2019), Asia (Chung et al. 2015; Kaufman et al. 2015), Africa (Vercammen-Grandjean \& Brennan 1957; Heyne et al. 2001), Oceania (McCulloch 1946), and America (Floch \& Abonnenc 1941; Michener 1946; Jenkins 1949; Brennan \& Yunker 1964; Sampaio et al. 2020), still few records when compared to the diversity of this family. In the present study, we provide the second record of trombiculiasis on a dog from Brazil. Emphasizing the importance of trombiculiasis records in national territory and in the world, since dermatitis caused by chiggers is understudied due to the difficulty of finding the mites or obtaining the correct identification.

\section{Acknowledgements}

To Gabrielle Ribeiro de Andrade and Maria Cristina Ferreira do Rosário for technical contribution. This work was supported by the Fundação de Amparo à Pesquisa do Estado de São Paulo under the Grant FAPESP no. 2019/19853-0 (FCJ), 2017/01416-7, 2018/246678 and 2020/11755-6 (RB-S). This study was financed in part by the Coordenação de Aperfeiçoamento de Pessoal de Nível Superior - Brasil (CAPES) - Finance Code 001.

\section{Authors' Contributions}

KMQA, FCGC and GB detected the mite in association with the dog and performed the treatment. FCJ and RB-S performed the study and confirmed the identification of the mites. RS-R and $\mathrm{MH}-\mathrm{B}$ performed the mite's preparations and wrote the manuscript with input from all authors.

\section{References}

Apesteguía, A. M.; Portell, A. J. B.; Kassab, H. N.; Salinas, G. M. J. (2019) Severe trombiculiasis in hunting dogs infested with Neotrombicula inopinata (Acari: Trombiculidae). Journal of Medical Entomology, 56(5): 1389-1394. doi: 10.1093/jme/tjz071

Barros-Battesti, D. M.; Jacinavicius, F. C.; Bauchan, G.; Bassini-Silva, R. (2021) Chapter 24: Techniques for studies on Acariformes. In: Barros-Battesti, D. M.; Machado, R. Z.; André, M. R. (Eds.), Brazilian ectoparasite fauna of veterinary importance, Volume 1, Mite fauna of veterinary importance: Acariformes, pp. 294-303. Jaboticabal: CBPV.

Bassini-Silva, R.; Jacinavicius, F. C.; Muñoz-Leal, S.; Maturano, R.; Welbourn, W. C.; Ochoa, R.; Bauchan, G. R.; Barros-Battesti, D. M. (2018) A new species of the genus Eutrombicula Ewing, 1938 (Trombidiformes: Trombiculidae) and new records for the species Eutrombicula batatas (Linnaeus, 1758) in Brazil. Acarologia, 58: 976-986. doi: 10.24349/acarologia/20184304

Bassini-Silva, R.; Jacinavicius, F. C.; Pinter, A.; Fournier, G. F. S. R.; Lugarini, C.; Ferreira, A.; Moreira-Lima, L.; Hingst-Zaher, E.; Welbourn, C.; Ochoa, R.; Barros-Battesti, D. M. (2019) Eutrombicula tinami (Oudemans, 1910) (Trombidiformes: Trombiculidae) in Brazil: a neglected ectoparasite of several animals including humans. Acarologia, 59: 412-423. doi: 10.24349/acarologia/20194343 
Brennan, J. M.; Yunker, C. E. (1964) A new species of Euschoengastia of potential veterinary importance (Acarina: Trombiculidae). The Journal of Parasitology, 50: 311-312. https://www.ncbi.nlm.nih. gov/pubmed/14170772

Chung, L. H.; Wu, W. J.; Kuo, C. C.; Wang, H. C. (2015) A checklist of chigger mites (Acari: Trombiculidae and Leeuwenhokiidae) from Taiwan, with descriptions of three new species. Journal of Medical Entomology, 52(6): 1241-1253. doi: 10.1093/jme/tjv139

Faccini, J. L. H.; Santos, A. C. G.; Santos, S. B.; Jacinavicius, F. C.; BassiniSilva, R.; Barros-Battesti D. M. (2017) Trombiculiasis in domestic goats and humans in the state of Maranhao, Brazil. Revista Brasileira De Parasitologia Veterinaria, 26: 104-109. doi: 10.1590/ S1984-29612016088

Fain, A.; Le Net, J.-L. (2000) A new larval mite of the genus Straelensia Vercammen-Grandjean and Kolebinova, 1968 (Acari: Leeuwenhoekiidae) causing nodular dermatitis of dogs in France. International Journal of Acarology, 26(4): 339-345. doi: 10.1080/01647950008684208

Floch, H.; Abonnenc, E. (1941) Trombidides de la Guyane Française. Le "pou d' agouti." Archives de I'Institut Pasteur de la Guyane française et de I'Inini, 20: 1-22.

Giannoulopoulos, G. D.; Desilla, L. J. S.; Desilla, E. S.; Papadopoulos, I.; Saridomichelakis, M. N. (2012) First report of Neotrombicula autumnalis infestation in a cat and a dog from Corfu (Greece) and in a cat from Limassol (Cyprus). Vector-Borne Zoonotic Dis, 12: 1065-1067. doi: 10.1089/vbz.2012.1062

Gonçalves-Souza, T.; Giupponi, A. P.; Hernandes, F. A. (2014) A rare finding of mites (Arachnida: Acari: Leeuwenhoekiidae) parasitising a whip spider (Arachnida: Amblypygi: Charinidae). Folia Parasitologica, 61(2): 182-184. doi: 10.14411/fp.2014.016

Heyne, H.; Ueckermann, E. A.; Coetzee, L. (2001) First report of a parasitic mite Leptotrombidium (Hypotrombidium) subquadratum (Lawrence) (Acari: Trombiculidae: Trombiculinae), from dogs and children in the Bloemfontein area, South Africa. Journal of the South African Veterinary Association, 72(2): 105-106

Jacinavicius, F. C.; Bassini-Silva, R.; Mendonza-Roldan, J. A.; Pepato, A. R.; Ochoa, R.; Welbourn, C.; Barros-Battesti, D. M. (2018) A checklist of chiggers from Brazil, including new records (Acari: Trombidiformes: Trombiculidae and Leeuwenhoekiidae). ZooKeys, 743: 1-41. doi: 10.389/zookeys.743.22675

Jenkins, D. W. (1949) Trombiculid mites affecting man IV. Revision of Eutrombicula in the American Hemisphere. Annals of the Entomological Society of America, 42(3): 289-318. doi: 10.1093/ aesa/42.3.289

Kaufmann, R.; Bourdeau, P.; Waldman, L.; Amiel, S.; Zur, G. (2015) Straelensiosis in two cats and ten dogs from Israel. Journal of Small Animal Practice, 56: 723-727. doi: 10.1111/jsap.12374

Lecru, L. A.; Combarros, D.; Castilla-Castaño, E.; Navarro, C.; Cadiergues, M. C. (2019) Treatment of harvest mite infestation in dogs using a permethrin $54.5 \%$ and fipronil $6.1 \%$ (Effitix ${ }^{\circledR}$ ) topical spot-on formulation. Journal of Veterinary Science, 6(4): 100. doi: 10.3390/ vetsci6040100

Mccullocher, N. (1946) Studies in the control of scrub typhus. The Medical Journal of Australia, 1: 717-738

Michener, C. D. (1946) Observations on the habits and life history of a chigger mite, Eutrombicula batatas (Acarina: Trombiculinae). Annals of the Entomological Society of America, 1: 101-118. doi 10.1093/aesa/39.1.101

Rocha, C. F. D.; Cunha-Barros, M.; Menezes, V. A.; Vrcibradic, D.; Kiefer, M. C.; Fontes, A. F.; Sluys, M. V.; Galdino, C. A. B.; Maia-Carneiro, T. (2020) High prevalence and intensity of infestation of Eutrombicula alfreddugesi (Acarina: Trombiculidae) on Tropidurus torquatus (Squamata, Tropiduridae): effects of body size and on body condition across ten populations along the Brazilian coast. Biologia, 75: 2231-2237. doi: 10.2478/s11756-020-00476-0

Sampaio, R. T. B.; Bassini-Silva, R.; Reis, N. M. O. R.; Welbourn, C.; Ochoa, R.; Barros-Battesti, D. M.; Jacinavicius, F. C. (2020) Eutrombicula daemoni Bassini-Silva and Jacinavicius, 2018 (Trombidiformes: Trombiculidae) parasitizing a dog in Brazil. International Journal of
Acarology, 46: 117-119. doi: 10.1080/01647954.2020.1718206

Shatrov, A. B.; Antonovskaia, A. A. (2021) Stylostome of the trombiculid mite larvae Neotrombicula talmiensis (Schluger, 1955) (Acariformes, Trombiculidae) feeding on two host species in the Russian Far East. Acarologia, 61(2): 412-431. doi: 10.24349/acarologia/20214442

Stekolnikov, A. A.; Waap, H.; Gomes, J.; Antunes, T. (2016) Chigger mites of the genus Ericotrombidium (Acariformes: Trombiculidae) attacking pets in Europe. Veterinary Parasitology, 221: 60-63. doi: 10.1016/j.vetpar.2016.03.009

Takahashi, M.; Urakami, H.; Nogami, S.; Kadosaka, T.; Misumi, H.; Matsumoto, I.; Misumi, M. (2004) Trombidiosis in cats caused by the bite of the larval trombiculid mite Helenicula miyagawai (Acari: Trombiculidae). Veterinary Record, 154(15): 471-472. doi: 10.1136/ vr.154.15.471

Vercammen-Grandjean, P. H.; Brennan, J. M. (1957) Eight new chiggers from East Africa and a new genus, Trombigastia (Acarina: Trombiculidae). Annals of the Entomological Society of America, 50: 484-496.

Zhang, Z.-Q.; Fan, Q.-H.; Pešić, V.; Smit, H.; Bochkov, A. V.; Khaustov, A. A.; Baker, A.; Wohltmann, A.; Wen, T.; Amrine, J. W. et al. (2011) Order Trombidiformes Reuter 1909. In: Zhang ZQ (Ed.), Animal biodiversity: an outline of higher-level classification and survey of taxonomic richness. Zootaxa, 3148(1): 129-138. doi: 10.11646/ zootaxa.3148.1.24 